\title{
PENYELESAIAN MASALAH BANGUN DATAR SISWA KELAS VII: KESALAHAN DAN KATEGORISASINYA
}

\author{
Nelly Silitonga ${ }^{1}$, Febrian $^{2}$ \\ wellynelysltg@gmail.com ${ }^{1}$, febrian@umrah.ac.id ${ }^{2}$ \\ Program Studi Pendidikan Matematika, Fakultas Keguruan dan Ilmu Pendidikan \\ Universitas Maritim Raja Ali Haji \\ 2016
}

\begin{abstract}
Abstrak
Studi ini bertujuan untuk menganalisa kesalahan siswa dalam mengerjakan soal bangun datar menggunakan kategori kesalahan Watson. Studi ini menggunakan studi deskriptif dengan pendekatan kualitatif. Studi ini dilakukan di kelas VII F SMP Negeri 10 Tanjungpinang tahun ajaran 2015/2016 dengan jumlah siswa sebanyak 38 siswa. Data didapatkan dari hasil jawaban tertulis siswa. Berdasarkan hasil analisis data, diperoleh siswa melakukan (1) kesalahan data tidak tepat (inappropriate data/id) sebebesar 54,29\%, (2) kesalahan prosedur tidak tepat (innappropriate procedure/ip) sebesar 18,86\%, (3) kesalahan data hilang (ommited data/ od) sebesar 6,86\%, (4) kesalahan kesimpulan hilang (ommited conclusion) sebesar 7,43\%, (5) kesalahan konflik level respon (response level conflict) sebesar 15,43\%, (6) kesalahan manipulasi tidak langsung (undirected manipulation) tidak ditemukan pada jawaban siswa, (7) kesalahan masalah hirarki keterampilan (skill hierarchy problem) sebesar 38,29\%.
\end{abstract}

Kata Kunci: studi deskriptif kualitatif, kategori kesalahan menurut Watson.

\begin{abstract}
This study was conducted to analyze students' error while solving problems of two dimensional object by using Watson error categorization. This qualitative study is presented descriptively. The study was undertaken in class VII F of SMP Negeri 10 Tanjungpinang in academic year 2015/2016. There were 38 students participating in this study. Data was obtained from students' answer on written test. Based on analysis result, it was obtained that students emerged (1) $54.29 \%$ for inappropriate data; (2) $18.86 \%$ for inappropriate procedure; (3) $6.86 \%$ for omitted data; (4) $7.43 \%$ for omitted conclusion; (5) $15.43 \%$ for response level conflict; (6) $0 \%$ for undirected manipulation; (7) $38.29 \%$ for skill hierarchy problem.
\end{abstract}

Keywords: qualitative descriptive study, Watson students' error categorization

\section{Pendahuluan}

\section{Latar belakang}

Matematika merupakan mata pelajaran yang mempelajari suatu objek yang abstrak (Soedjadi 2011). Objek dasar matematika terdiri dari fakta, konsep, defenisi, operasi, dan prinsip. Oleh karena itu belajar matematika haruslah bertahap dan sistematis.

Matematika merupakan pelajaran yang wajib pada semua tingkatan pendidikan. Sejak duduk di bangku sekolah dasar kita sudah dikenalkan dengan matematika.Mata pelajaran ini menduduki posisi yang sangat penting karena memliki peran dalam berbagai dimensi kehidupan.

Sungguh ironis jika matematika menjadi salah satu mata pelajaran yang tidak disenangi bahkan ditakuti oleh peserta didik. Beberapa siswa menganggap matematika itu sulit, banyak rumus yang harus dihafal. Akibatnya banyak 
siswa hanya mengandalkan hafalan rumus, sehingga tidak jarang ditemui kesalahankesalahan siswa dalam mengerjakan soal-soal matematika.

Sering juga dijumpai siswa yang mengalami kesulitan dalam memahami soal-soal matematika sehingga siswa seringkali melakukan kesalahan-kesalahan dalam menyelesaikan soal yang diberikan. Dalam hal ini, guru sangat berperan penting untuk membantu siswa mempelajari matematika untuk meminimalkan kesalahan-kesalahan siswa dalam menjawab soal matematika. Kesalahan yang dilakukan oleh siswa harus segera mendapat pemecahan dan solusi yang tepat.

Dalam penelitian yang dilaksanakan di SMP Negeri 10 Tanjungpinang dengan materi pokok bahasan bangun datar maka penulis mengkategorikan kesalahan siswa menggunakan teori Watson. Menurut Watson (dalam Sunardi, 1995) terdapat 8 kategori kesalahan dalam mengerjakan soal, yaitu:

1. Data tidak tepat (inappropriate data/ id). Dalam kasus ini siswa berusaha mengoperasikan pada level yang tepat pada suatu masalah, tetapi memilih sebuah informasi atau data yang tidak tepat.

2. Prosedur tidak tepat (inappropriate procedure/ ip). Pada kasus ini siswa berusaha mengoperasikan pada level yang tepat pada suatu masalah, tetapi dia menggunakan prosedur atau cara yang tidak tepat. Contohnya

3. Data hilang (ommited data/ od). Data hilang yaitu kehilangan satu data atau lebih dari respon siswa. Dengan demikian penyelesaian menjadi tidak benar. Mungkin respon siswa tidak menemukan informasi yang tepat, namun mahasiswa masih berusaha mengoperasikan pada level yang tepat.

4. Kesimpulan hilang (ommited conclusion/ oc). Gejala kesimpulan hilang adalah siswa menunjukkan alasan pada level yang tepat kemudian gagal menyimpulkan.

5. Konflik level respon (response level conflict) $r l c$ ). Gejala yang terkait dengan respon kesimpulan hilang adalah konflik level respon. Pada situasi ini siswa menunjukkan suatu kompetisi operasi pada level tertentu dan kemudian menurunkan ke operasi yang lebih rendah, biasanya untuk kesimpulan.

6. Manipulasi tidak langsung (undirected manipulation/ um). Alasan tidak urut tetapi kesimpulan didapat dan secara umum semua data digunakan. Suatu jawaban benar diperoleh dengan menggunakan alasan yang sederhana dan penuangan tidak logis atau acak.

7. Masalah hirarkhi keterampilan (skills hierarchy problem/ shp). Banyak pertanyaan matematika memerlukan beberapa keterampilan untuk dapat menyelesaikannya seperti keterampilan yang melibatkan kemampuan menggunakan ide aljabar dan keterampilan memanipulasi numerik.Jika keterampilan siswa dalam aljabar atau memanipulasi numerik tidak muncul, terjadi masalah hirarkhi keterampilan.

8. Selain ketujuh kategori di atas (above other/ $a o$ ). Kesalahan siswa yang tidak termasuk pada ketujuh kategori di atas dikelompokkan dalam kategori ini.

\section{Tujuan Studi}

Untuk mengetahui jenis-jenis kesalahan yang dilakukan siswa dalam menyelesaikan soal-soal bangun datar.

\section{Pertanyaan Studi}

1. Apa saja jenis kesalahan siswa dalam menyelesaikan permasalahan bidang datar berdasarkan kategori kesalahan menurut Watson?

2. Berapa persentase siswa yang melakukan kesalahan Kn pada masing-masing soal dalam menyelesaikan permasalahan bangun datar?

3. Berapa persentase kesalahan siswa untuk semua soal dalam menyelesaikan permasalahan bangun datar berdasarkan kategori kesalahan menurut watson?

4. Kesalahan apakah yang dominan muncul pada masing-masing soal?

\section{II.Metode}

\section{Pendekatan dan Jenis Studi}

Jenis studi ini adalah studi deskriptif dengan menggunakan pendekatan kualitatif. 
Studi deskriptif merupakan salah satu cara studi dengan menggambarkan serta menginterpretasi suatu objek sesuai dengan kenyataan yang ada, tanpa dilebih-lebihkan. Pendekatan kualitatif adalah suatu pendekatan yang juga disebut pendekatan investigasi karena biasanya peneliti mengumpulkan data dengan cara bertatap muka langsung dan berinteraksi dengan orang-orang di tempat penelitian (McMillan \& Schumacher, 2003).

\section{Subjek studi}

Studi ini dilaksanakan di SMP Negeri 10 Tanjungpinang kepada siswa kelas VII $\mathrm{F}$ semester 2 tahun pelajaran 2015/2016 dengan jumlah 38 siswa, terdiri dari 15 siswa laki-laki dan 20 siswa perempuan. Pada saat pelaksanaan tes tertulis ada 3 siswa yang tidak mengikuti tes. Sehingga total siswa yang mengikuti tes sebanyak 35 siswa.

\section{Instrumen}

Soal-soal bangun datar dalam studi ini adalah soal tes tertulis essay yang terdiri dari lima butir soal, yang diujikan kepada siswa yang telah ditentukan sebagai subjek studi. Soal tersebut dibuat berdasarkan materi bangun datar dengan waktu pengerjaan soal sekitar 80 menit yang sebelumnya sudah dikosultasikan dengan guru matematika kelas VII F SMP Negeri 10 Tanjungpinang oleh Ibu Laila.

Soal tes terdiri dari:

1. soal pemecahan masalah luas dan keliling bangun segitiga,

2. soal pemecahan masalah dari luas bangun lingkaran yang ditentukan kelilingnya,

3. soal pemecahan masalah dari keliling bangun datar segi tidak beraturan

4. soal pemecahan masalah dari luas bangun datar segi tidak beraturan

5. soal tentang pemecahan masalah suatu luas bangun datar segi tidak beraturan.

\section{Pengumpulan Data}

Data didapatkan dari hasil jawaban tertulis siswa. Dalam kegiatan ini siswa diminta menuliskan jawabannnya ke lembar jawaban yang telah dibagikan. Lembar ini menjadi menjadi sumber yang tepat bagi penulis untuk menganalisa jawaban siswa.

\section{Proses Analisa}

Pertama, sebelum menganalisa kesalahan siswa dalam menyelesaikan permasalahan bangun datar, pengamat memahami dan menguasai terlebih dahulu setiap kategori kesalahan menurut Watson.

Kedua, satu orang pengamat menganalisa satu per satu lembar jawaban siswa. Apabila pengamat menemukan kesalahan yang sulit untuk di kategorikan menurut Watson, maka akan dilakukan diskusi bersama.

Ketiga, setelah setiap pengamat selesai menganalisa jawaban siswa, maka jawaban kembali diperiksa oleh pengamat lainnya (cross checking). Hal ini dilakukan untuk meminimalisir kekeliruan pengamat dalam mengkategorikan kesalahan siswa agar hasil analisis yang didapat lebih akurat.

Keempat, pengamat melakukan rekapitulasi hasil analisa dalam bentuk tabel.

\section{Hasil dan Pembahasan}

(Lihat Tabel 2 Matriks Kesalahan Siswa Kelas VII F SMP Negeri 10 Tanjungpinang Pada Materi Bangun Datar)

\section{Persentase Siswa Yang Melakukan Kesalahan Kn Pada Masing-masing Soal}

Untuk menghitung persentase siswa yang melakukan kesalahan Kn pada masingmasing soal, penulis menggunakan rumus:

$$
\mathrm{P}=\frac{n(S)}{\sum N} \mathrm{x} 100 \%
$$

Dimana:

$\mathrm{P}(\mathrm{s})=$ persentase jumlah siswa yang melakukan kesalahan Kn pada soal ke-n,

$\mathrm{n}(\mathrm{s})=$ jumlah siswa yang melakukan kesalahan Kn pada soal ke-n,

$\sum N=$ jumlah seluruh siswa.

Hasil analisis data menunjukkan persentase siswa yang melakukan kesalahan data tidak tepat (inappropriate data/ id) pada soal nomor 1 sebesar $100 \%$, pada soal nomor 2 sebesar $60 \%$, pada soal nomor 3 sebesar $42,86 \%$, 
JURNAL GANTANG Pendidikan Matematika FKIP - UMRAH

Vol. 1 No. 2, Desember 2016, p-ISSN. 2503-0671, e-ISSN. 2548-5547

pada soal nomor 4 sebesar $31,43 \%$, sedangkan pada soal nomor 5 sebesar $37,14 \%$.

Persentase siswa melakukan kesalahan prosedur tidak tepat (innappropriate procedure/ ip) pada soal nomor 1 sebesar $0 \%$, pada soal nomor 2 sebesar $8,57 \%$, pada soal nomor 3 sebesar $42,86 \%$, pada soal nomor 4 sebesar $31,43 \%$, sedangkan pada soal nomor 5 sebesar $11,43 \%$.

Persentase siswa melakukan kesalahan data hilang (ommited datal od) pada soal nomor 1, 2, 4, dan 5 sebesar $0 \%$, sedangkan pada soal nomor 3 sebesar $34,29 \%$.

Persentase siswa melakukan kesalahan kesimpulan hilang (ommited conclusion) pada soal nomor 1 dan 3 sebesar 0\%, sedangkan pada soal nomor 2 sebesar $14,28 \%$, pada soal nomor 4 sebesar $5,71 \%$, pada soal nomor 5 sebesar $17,14 \%$.

Persentase siswa yang melakukan kesalahan konflik level respon (response level conflict) pada soal nomor 1 dan 2 sebesar $0 \%$, sedangkan pada soal nomor 3 sebesar $28,57 \%$, pada soal nomor 4 sebesar $40 \%$, pada soal nomor 5 sebesar $8,57 \%$.

Persentase siswa yang melakukan kesalahan masalah hirarkhi keterampilan (skills hierarchy problem) pada soal nomor 1 sebesar $14,29 \%$, pada soal nomor 2 sebesar $37,14 \%$, pada soal nomor 3 sebesar $65,71 \%$, pada soal nomor 4 sebesar $34,29 \%$, pada soal nomor 5 sebesar $31,43 \%$.

\section{Persentase Kesalahan Siswa Untuk Seluruh Soal}

Untuk menghitung persentase frekuensi kesalahan masing-masing kategori, penulis menggunakan rumus:

$$
\mathrm{P}=\frac{n(S)}{\sum N} \mathrm{x} 100 \%
$$

Dimana:

$\mathrm{P}(\mathrm{s})=$ persentase kesalahan masing-masing kategori kesalahan,

$\mathrm{n}(\mathrm{s})=$ jumlah kesalahan untuk masing kategori kesalahan,

$\sum N=$ banyaknya kesalahan untuk seluruh kategori kesalahan.
Berikut klasifikasi persentase jenis kesalahan yang dilakukan oleh siswa menurut Mutejo (dalam Mujayanti 2011:31):

Tabel 1 Klasifikasi Persentase Jenis Kesalahan

\begin{tabular}{|c|c|}
\hline Persentase & Kategori \\
\hline $\mathrm{P} \geq 55 \%$ & Sangat tinggi \\
$40 \% \leq \mathrm{P}<55 \%$ & Tinggi \\
$25 \% \leq \mathrm{P}<40 \%$ & Cukup tinggi \\
$10 \% \leq \mathrm{P}<25 \%$ & Kecil \\
$\mathrm{P}<10 \%$ & Sangat kecil \\
\hline
\end{tabular}

Hasil analisis data menunjukkan persentase siswa melakukan kesalahan data tidak tepat (inappropriate data/ id) untuk seluruh soal sebebesar 54,29\%. Ini menunjukkan kategori kesalahan yang tinggi. Soal nomor 1 kesalahan data tidak tepat sebesar $20 \%$, pada soal nomor 2 sebesar $12 \%$, pada soal nomor 3 sebesar 8,57\%, pada soal nomor 4 sebesar 6,29\%, pada soal nomor 5 sebesar $7,43 \%$.

Persentase siswa yang melakukan kesalahan prosedur tidak tepat (innappropriate procedurel ip) untuk seluruh soal sebesar $18,86 \%$. Ini menunjukkan kategori kesalahan yang kecil. Kesalahan prosedur yang tidak tepat terjadi pada nomor 2 sebesar $1,71 \%$, pada soal nomor 3 sebesar $8,57 \%$, pada soal nomor 4 sebesar 6,29\%, sedangkan pada soal nomor 5 sebesar 2,29\%.

Persentase siswa melakukan kesalahan Data hilang (ommited data/ od) untuk seluruh soal sebesar $6,86 \%$. Ini menunjukkan kategori kesalahan yang sangat kecil. Kesalahan data hilang terjadi pada soal nomor 3 .

Persentase siswa melakukan kesalahan kesimpulan hilang (ommited conclusion) untuk seluruh soal sebesar 7,43\%. Ini menunjukkan kategori kesalahan yang sangat kecil. Kesalahan kesimpulan hilang terjadi pada nomor 2 sebesar 
2,86\%, pada soal nomor 4 sebesar $1,14 \%$, sedangkan pada soal nomor 5 sebesar 3,43\%.

Persentase siswa melakukan kesalahan konflik level respon (response level conflict) untuk seluruh soal sebesar 15,43\%. Ini menunjukkan kategori kesalahan yang kecil. Kesalahan konflik level respon terjadi pada nomor 3 sebesar $5,71 \%$, pada soal nomor 4 sebesar $8 \%$, sedangkan pada soal nomor 5 sebesar $1,71 \%$.

Persentase kesalahan manipulasi tidak langsung (undirected manipulation/ um) untuk seluruh soal adalah $0 \%$ artinya tidak ditemukan kesalahan um. Ini menunjukkan kategori kesalahan yang sangat kecil.

Persentase siswa melakukan kesalahan masalah hirarkhi keterampilan (skills hierarchy problem) untuk seluruh soal sebesar 38,29\%. Ini menunjukkan kategori kesalahan yang cukup tinggi. Kesalahan masalah hirarki keterampilan terjadi hampir pada setiap soal. Soal nomor 1 sebesar $2,86 \%$, soal nomor 2 sebesar $7,43 \%$, soal nomor 3 sebesar $13,14 \%$, soal nomor 4 sebesar $6,86 \%$, sedangkan pada soal nomor 5 sebesar 6,29\%. Kesalahan K8 (above other) tidak ditemukan pada jawaban siswa.

\section{Kesalahan Yang Dominan Muncul Pada Masing-Masing Soal}

Pada soal nomor 1, kesalahan yang dominan muncul adalah kesalahan data tidak tepat (inappropriate datal id). Siswa yang melakukan kesalahan id sebesar $100 \%$. Berikut contoh kesalahan pada soal nomor 1:

1. sebuah segitiga sama sisi. Panjang sisinya $6 \mathrm{~cm}$. Hitunglah luas dan keliling segitiga tersebut!

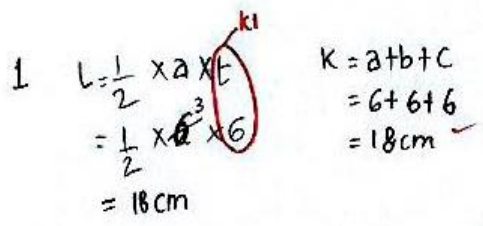

\section{Gambar 1. Kesalahan pada soal 1}

Dari hasil jawaban diatas terlihat bahwa siswa salah memasukkan data kedalam rumus.
Sehingga siswa tidak mendapatkan hasil yang tepat.

Pada soal nomor 2, kesalahan yang dominan muncul adalah data tidak tepat (inappropriate datal id) sebesar $60 \%$ dan masalah hirarkhi keterampilan (skills hierarcy problem/ shp) sebesar 37,14\%. Berikut contoh kesalahan siswa pada soal nomor 2:

2. Sebuah lingkaran memiliki keliling lingkaran $22 \mathrm{~cm}$. Hitunglah luas lingkaran tersebut!

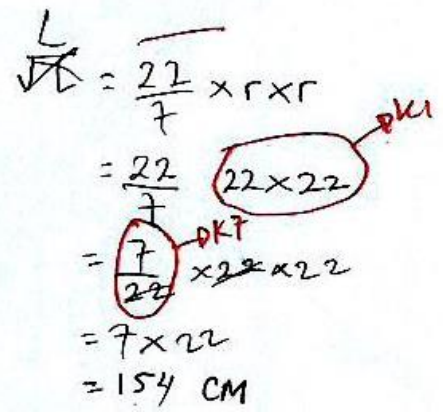

\section{Gambar 2. Kesalahan pada soal 2}

Dari hasil jawaban diatas terlihat bahwa siswa memasukkan data yang tidak tepat kedalam rumus. Selain itu siswa melakukan kekeliruan dalam menghitung.

Pada soal nomor 3, kesalahan yang dominan muncul adalahdata tidak tepat (inappropriate data/ id) sebesar8,57\%, prosedur tidak tepat (inappropriate procedure/ ip) sebesar $8,57 \%$, data hilang (ommited data/ od) sebesar $6,86 \%$, diikuti dengan masalah hirarkhi keterampilan (skills hierarchy problem/ shp) $13,14 \%$. Berikut contoh kesalahan siswa pada soal nomor 3:

3. Perhatikan gambar bangun datar berikut:

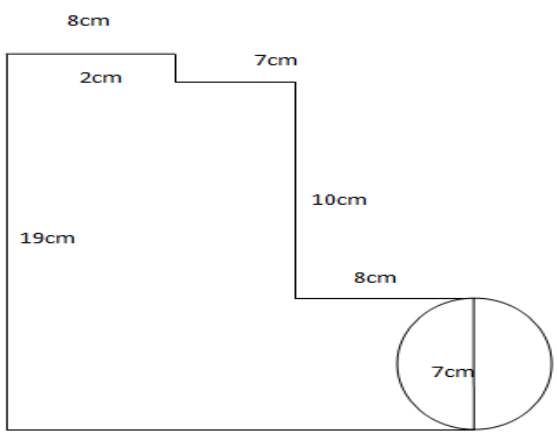

Gambar 3. Keliling bangun tersebut ... 


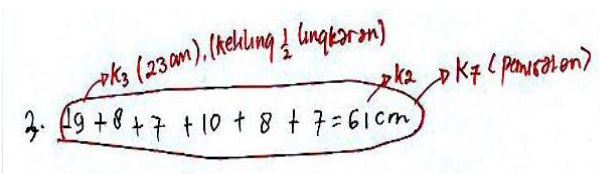

\section{Gambar 4. Jawaban soal 3}

Dari hasil jawaban siswa diatas terlihat bahwa siswa melakukan kesalahan shp yaitu siswa tidak memiliki keterampilan manipulasi data dalam menyelesaikan soal, sehingga prosedur yang digunakan dalam menyelesaikan soal tersebut kurang tepat. Selain itu terdapat beberapa data yang hilang dari jawaban siswa.

Pada soal nomor 4, kesalahan yang dominan muncul adalah data tidak tepat (inappropriate datal id) sebesar 31,43\%, prosedur tidak tepat (inappropriate procedurel ip) sebesar 31,43\%, konflik level respon (response level conflict/ rlc) sebesar 40\%, masalah hirarkhi keterampilan (skills hierarchy problem/ shp) 34,29\%. Berikut contoh kesalahan pada soal nomor 4 :

4. Perhatikan gambar pada soal nomor 4. Hitunglah luas bangun tersebut!

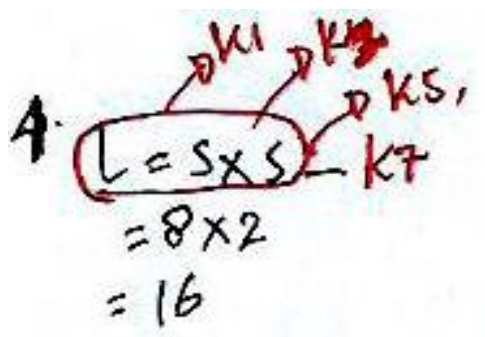

\section{Gambar 5. Kesalahan jawab pada soal 4}

Dari data ini dapat disimpulkan, siswa tidak menggunakan keterampilan dalam memanipulasi soal, sehingga prosedur serta rumus yang digunakan tidak tepat.

Kesalahan yang dominan muncul pada soal nomor 5 adalah data tidak tepat (inappropriate datal id) sebesar 37,14\%. kesimpulan hilang (ommited conclusion) sebesar 17,14\%, masalah hirarkhi keterampilan (skills hierarchy problem) sebesar 31,43\%.

Berikut contoh kesalahan yang dilakukan siswa pada soal nomor 5:

5. Perhatikan gambar berikut ini:

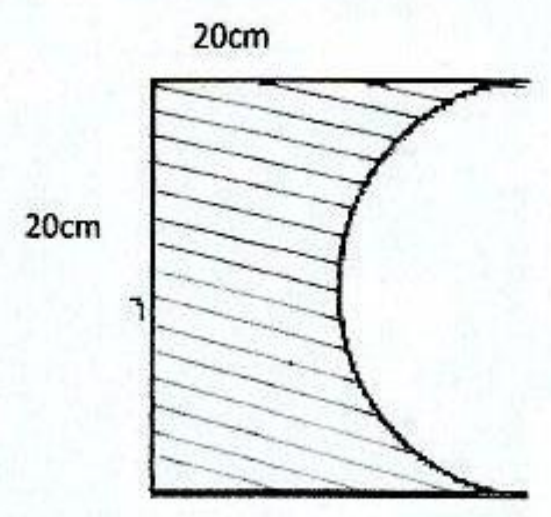

Gambar 6. Hitunglah daerah yang diarsir!

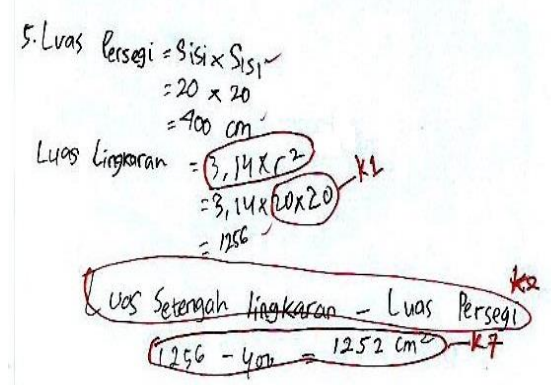

\section{Gambar 7. Kesalahan jawab soal 5}

Dari data ini, dapat dilihat siswa hampir menggunakan prosedur yang tepat yaitu dimulai dengan menghitung luas bangun datar persegi dan bangun datar lingkaran namun dalam menyimpulkan jawaban siswa menggunakan prosedur yang tidak tepat. Siswa juga kurang teliti dalam membaca soal sehingga data yang digunakan tidak tepat.

\section{Kesimpulan}

Berdasarkan hasil dan pembahasan dari data yang diperoleh dalam studi, maka dapat di ambil kesimpulan sebagai berikut:

1. Jenis kesalahan siswa dalam menyelesaikan permasalahan bangun datar berdasarkan kategori kesalahan menurut Watson adalah kesalahan data tidak tepat(inappropriate data/ id) terjadi pada seluruh soal yaitu soal nomor 1, 2, 3, 4, dan 5. Kesalahan prosuder tidak tepat (innappropriate procedure/ ip) terjadi pada soal nomor 2, 3, 4, dan 5. Kesalahan data hilang (omitted datal od) terjadi pada soal nomor 3. Kesalahan kesimpulan hilang 
(omitted conclusion/oc) terjadi pada soal nomor 2, 4, dan 5. Kesalahan konflik level respon (response level conflict/rlc) terjadi pada soal nomor 3, 4, dan 5. Pada kesalahan manipulasi tidak langsung (undirected manipulation/um) tidak ditemukan pada jawaban siswa. Kesalahan hierarki keterampilan (skills hierarchy problem/shp) terjadi pada seluruh nomor soal, nomor 1, 2, 3,4 , dan 5 .

2. Persentase siswa yang melakukan kesalahan untuk masing-masing soal dalam menyelesaikan permasalahan bangun datar berdasarkan kategori kesalahan Watson adalah kesalahan id pada soal nomor 1 sebesar $100 \%$, pada soal nomor 2 sebesar $60 \%$, pada soal nomor 3 sebesar $42,86 \%$, pada soal nomor 4 sebesar $31,43 \%$, dan pada soal nomor 5 sebesar $37,14 \%$. Kesalahan ip pada nomor 2 sebesar $8,57 \%$, pada soal nomor 3 sebesar $42,86 \%$, pada soal nomor 4 sebesar $31,43 \%$, pada soal nomor 5 sebesar $11,43 \%$. Kesalahan od pada soal nomor 3 sebesar 34,29\%. Kesalahan oc pada soal nomor 2 sebesar 14,28\%, pada soal nomor 4 sebesar 5,71\%, pada soal nomor 5 sebesar $17,14 \%$. Kesalahan rlc pada soal nomor 3 sebesar $28,57 \%$, pada soal nomor 4 sebesar $40 \%$, pada soal nomor 5 sebesar $8,57 \%$. Pada kesalahan um tidak ditemukan pada jawaban siswa. Kesalahan shp pada soal nomor 1 sebesar $14,29 \%$, pada soal nomor 2 sebesar $37,14 \%$, pada soal nomor 3 sebesar $65,71 \%$, pada soal nomor $34,29 \%$, pada soal nomor 5 sebesar $31,43 \%$.

3. Persentase jenis kesalahan siswa dalam menyelesaikan permasalahan bangun datar berdasarkan kategori kesalahan menurut Watson adalah kesalahan data tidak tepat (inappropriate data/id) sebesar 54,29\%. Kesalahan prosedur tidak tepat (inappropriate procedure/ip) sebesar $18,86 \%$. Kesalahan data hilang (omitted data/od) sebesar 6,86\%. Kesalahan kesimpulan hilang (omitted conclusion) sebesar 7,43\%. Kesalahan konflik level respon (response level conflict/rlc) sebesar 15,43\%. Pada kesalahan manipulasi tidak langsung (undirected manipulation/um) tidak ditemukan pada jawaban siswa.

4. Pada soal nomor 1, kesalahan yang dominan muncul adalah kesalahan $i d$. Pada soal nomor 2 , kesalahan yang dominan muncul adalah kesalahan id dan kesalahan shp. Pada soal nomor 3, kesalahan yang dominan muncul adalah kesalahan $i d$, kesalahan $i p$, kesalahan $o d$, diikuti dengan masalah shp. Pada soal nomor 4, kesalahan yang dominan muncul adalah kesalahan $i d$, kesalahan $i p$, kesalahan $r l c$, masalah shp. Kesalahan yang dominan muncul pada soal nomor 5 adalah data tidak tepat (inappropriate data/id), kesimpulan hilang (ommited conclusion), masalah hirarkhi keterampilan (skills hierarchy problem).

Saran yang dapat diberikan adalah:

1. Guru sebaiknya banyak memberikan latihan soal yang bervariasi agar dapat dikerjakan siswa serta pada saat pembelajaran perlu menekankan tentang pemahaman konsep.

2. Lebih banyak mengingatkan, menekankan kepada siswa tentang ketelitian dalam memasukkan data.

3. Siswa sebaiknya banyak berlatih mengerjakan soal-soal bangun datar.

Tabel 2 Matriks Kesalahan Siswa Kelas VII F SMP N 10 Tanjungpinang Berdasarkan Kategori Watson Dalam Menyelesaikan Permasalahan Bangun Datar

\begin{tabular}{|c|c|c|c|c|c|c|c|c|c|c|}
\hline No. & Nama Siswa & Soal & K1 & K2 & K3 & K4 & K5 & K6 & K7 & K8 \\
\hline \multirow{4}{*}{1} & \multirow{4}{*}{ Agus Herbudin } & 1 & $\mathbf{V}$ & & & & & & & \\
\cline { 3 - 13 } & & 2 & & & & & & & & \\
\cline { 3 - 13 } & & 3 & $\mathbf{V}$ & $\mathbf{V}$ & $\mathbf{V}$ & & & & $\mathbf{V}$ & \\
\hline & & 5 & $\mathbf{V}$ & $\mathbf{V}$ & & & $\mathbf{V}$ & & $\mathbf{V}$ & \\
\hline & & 1 & $\mathbf{V}$ & & & & & & & \\
\hline & & & & & & & & & & \\
\hline
\end{tabular}


JURNAL GANTANG Pendidikan Matematika FKIP - UMRAH

Vol. 1 No. 2, Desember 2016, p-ISSN. 2503-0671, e-ISSN. 2548-5547

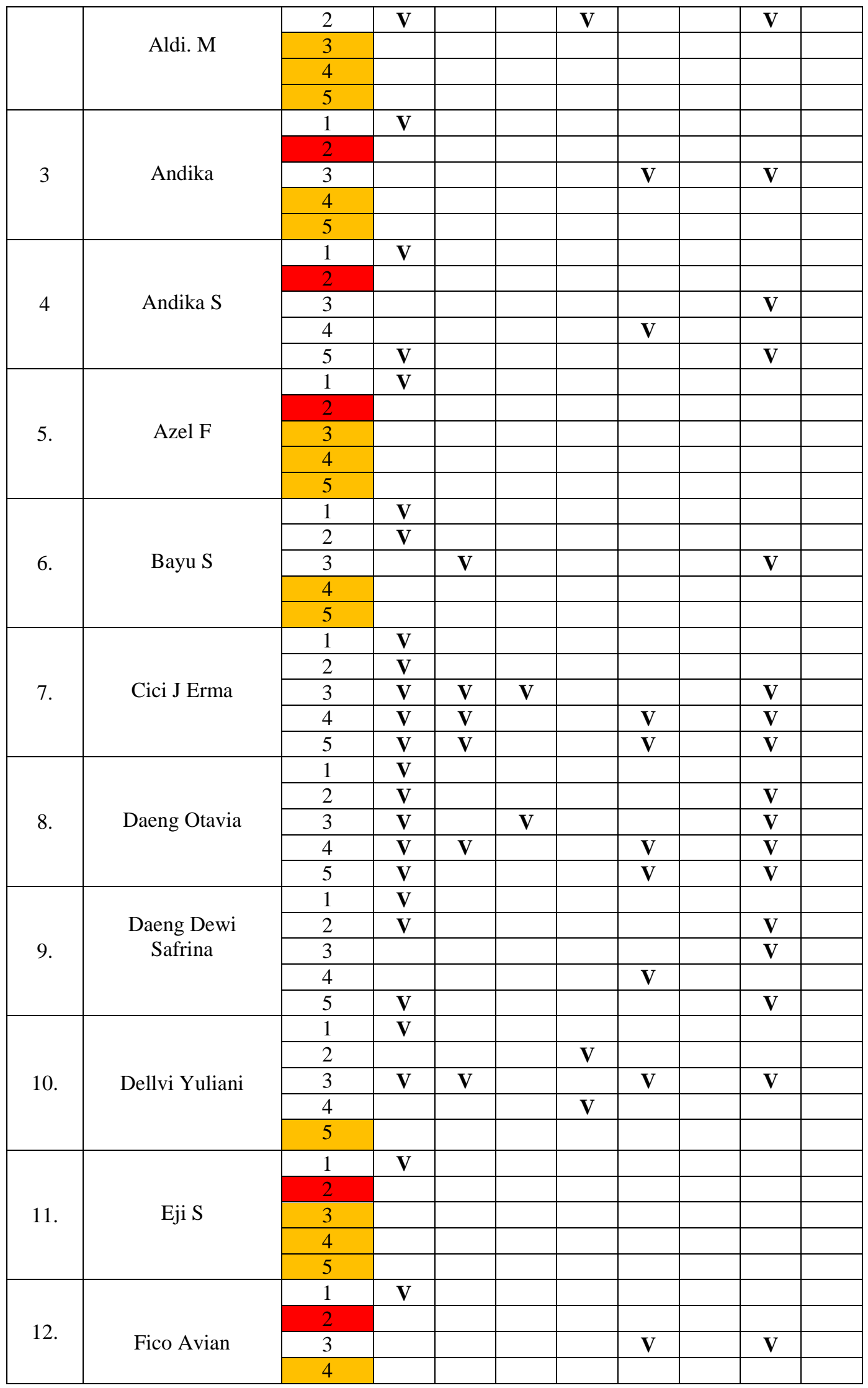


JURNAL GANTANG Pendidikan Matematika FKIP - UMRAH

Vol. 1 No. 2, Desember 2016, p-ISSN. 2503-0671, e-ISSN. 2548-5547

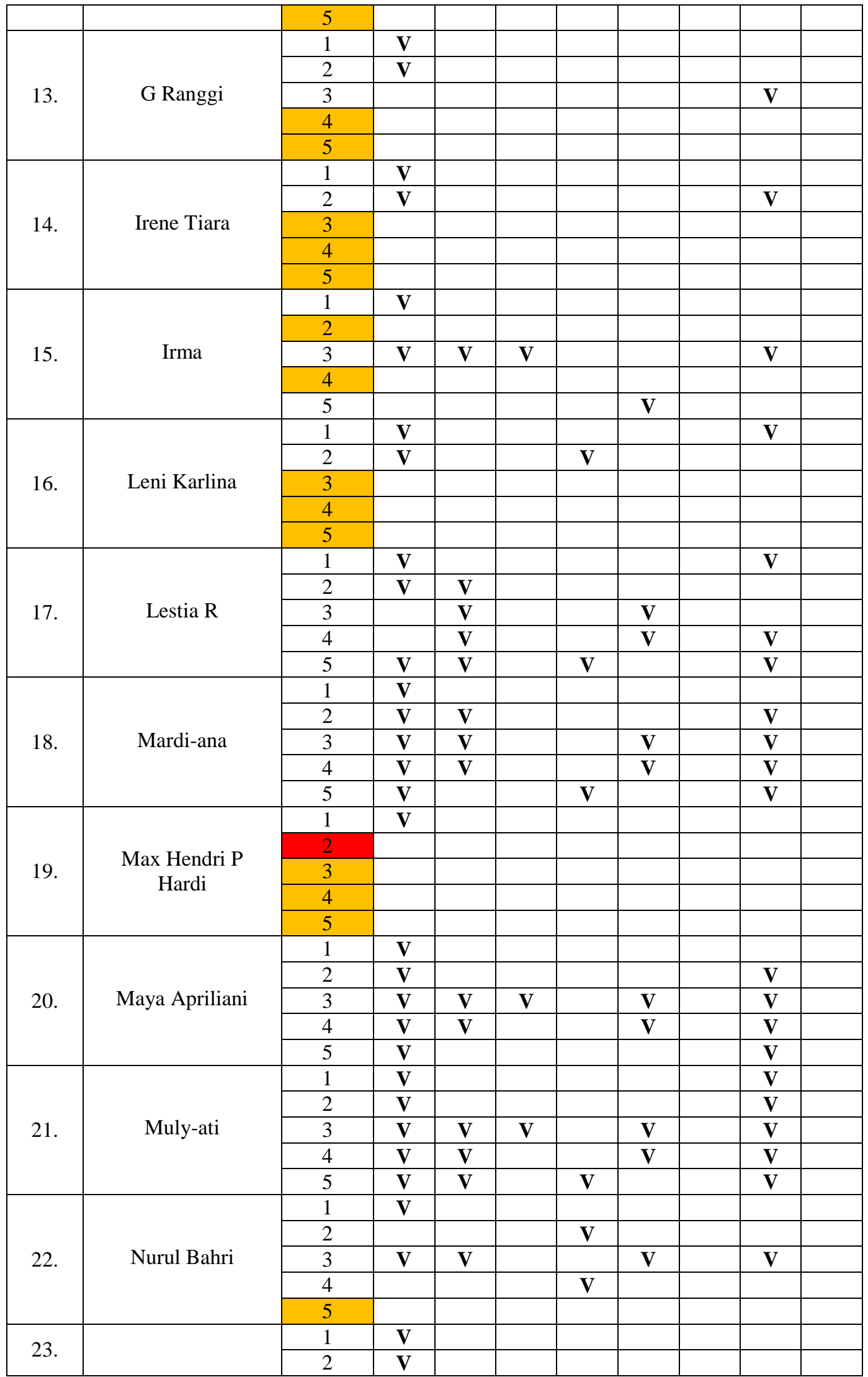


JURNAL GANTANG Pendidikan Matematika FKIP - UMRAH

Vol. 1 No. 2, Desember 2016, p-ISSN. 2503-0671, e-ISSN. 2548-5547

\begin{tabular}{|c|c|c|c|c|c|c|c|c|c|}
\hline & \multirow[t]{3}{*}{ Prengki Boy } & 3 & & & & & & & \\
\hline & & 4 & & & & & & & \\
\hline & & 5 & & & & & & & \\
\hline \multirow{5}{*}{24.} & \multirow{5}{*}{ Rasidi } & 1 & $\mathbf{V}$ & & & & & & \\
\hline & & 2 & & & & & & & \\
\hline & & 3 & & $\mathbf{V}$ & $\mathbf{V}$ & & & $\mathbf{V}$ & \\
\hline & & 4 & & & & & & & \\
\hline & & 5 & & & & & & & \\
\hline \multirow{5}{*}{25.} & \multirow{5}{*}{ Rici Riando } & 1 & $\mathbf{V}$ & & & & & & \\
\hline & & 2 & & & & & & & \\
\hline & & 3 & $\mathbf{V}$ & $\mathbf{V}$ & $\mathbf{V}$ & & & $\mathbf{V}$ & \\
\hline & & 4 & & & & & & & \\
\hline & & 5 & & & & & & & \\
\hline \multirow{5}{*}{26.} & \multirow{5}{*}{ Rio Candra } & 1 & $\mathbf{V}$ & & & & & & \\
\hline & & 2 & & & & & & & \\
\hline & & 3 & & & & & & & \\
\hline & & 4 & & & & & & & \\
\hline & & 5 & & & & & & & \\
\hline \multirow{5}{*}{27.} & \multirow{5}{*}{ Ririn $S$} & 1 & $\mathbf{V}$ & & & & & & \\
\hline & & 2 & $\mathbf{V}$ & & & & & $\mathbf{V}$ & \\
\hline & & 3 & $\mathbf{V}$ & & & & $\mathbf{V}$ & $\mathbf{V}$ & \\
\hline & & 4 & $\mathbf{V}$ & & & & $\mathbf{V}$ & $\mathbf{V}$ & \\
\hline & & 5 & $\mathbf{V}$ & & & & & $\mathbf{V}$ & \\
\hline \multirow{5}{*}{28.} & \multirow{5}{*}{ Sakria Azan syah } & 1 & $\mathbf{V}$ & & & & & & \\
\hline & & 2 & $\mathbf{V}$ & & & & & & \\
\hline & & 3 & & & & & & $\mathbf{V}$ & \\
\hline & & 4 & & & & & & & \\
\hline & & 5 & & & & & & & \\
\hline \multirow{5}{*}{29.} & \multirow{5}{*}{ Sarita } & 1 & $\mathbf{V}$ & & & & & & \\
\hline & & 2 & $\mathbf{V}$ & $\mathbf{V}$ & & $\mathbf{V}$ & & $\mathbf{V}$ & \\
\hline & & 3 & $\mathbf{V}$ & $\mathbf{V}$ & $\mathbf{V}$ & & & $\mathbf{V}$ & \\
\hline & & 4 & V & $\mathbf{V}$ & & & $\mathbf{V}$ & V & \\
\hline & & 5 & $\mathbf{V}$ & & & $\mathbf{V}$ & & $\mathbf{V}$ & \\
\hline \multirow{5}{*}{30.} & \multirow{5}{*}{ Septia Widia Putri } & 1 & $\mathbf{V}$ & & & & & $\mathbf{V}$ & \\
\hline & & 2 & $\mathbf{V}$ & & & & & $\mathbf{V}$ & \\
\hline & & 3 & V & $\mathbf{V}$ & $\mathbf{V}$ & & $\mathbf{V}$ & V & \\
\hline & & 4 & $\mathbf{V}$ & $\mathbf{V}$ & & & $\mathbf{V}$ & $\mathbf{V}$ & \\
\hline & & 5 & $\mathbf{V}$ & V & & $\mathbf{V}$ & & $\mathbf{V}$ & \\
\hline \multirow{5}{*}{31.} & \multirow{5}{*}{ Silvia A } & 1 & $\mathbf{V}$ & & & & & & \\
\hline & & 2 & $\mathbf{V}$ & & & & & $\mathbf{V}$ & \\
\hline & & 3 & $\mathbf{V}$ & V & $\mathbf{V}$ & & & $\mathbf{V}$ & \\
\hline & & 4 & $\mathbf{V}$ & $\mathbf{V}$ & & & $\mathbf{V}$ & $\mathbf{V}$ & \\
\hline & & 5 & & & & & & & \\
\hline & & 1 & $\mathbf{V}$ & & & & & $\mathbf{V}$ & \\
\hline & & 2 & $\mathbf{V}$ & & & & & $\mathbf{V}$ & \\
\hline 32. & Siti F & 3 & $\mathbf{V}$ & & $\mathbf{V}$ & & & $\mathbf{V}$ & \\
\hline & & 4 & $\mathbf{V}$ & $\mathbf{V}$ & & & $\mathbf{V}$ & $\mathbf{V}$ & \\
\hline & & 5 & $\mathbf{V}$ & & & $\mathbf{V}$ & & & \\
\hline & & 1 & $\mathbf{V}$ & & & & & & \\
\hline & & 2 & $\mathbf{V}$ & & & & & $\mathbf{V}$ & \\
\hline 33. & Tasya Nadila Putri & 3 & & & & & & & \\
\hline & & 4 & & & & & & & \\
\hline & & 5 & & & & & & & \\
\hline
\end{tabular}




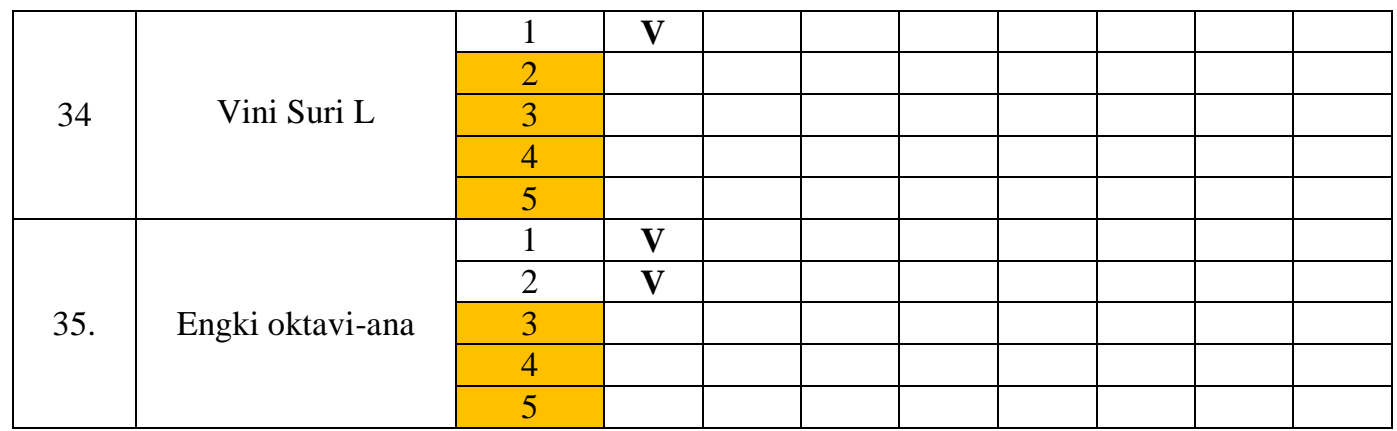

\section{Keterangan :}

$\begin{array}{ll}\text { K1 } & \text { : Data tidak tepat (inappropriate data/ id). } \\ \text { K2 } & \text { : Prosedur tidak tepat (inappropriate procedure/ ip). } \\ \text { K3 } & \text { : Data hilang (ommited data/ od). } \\ \text { K4 } & \text { : Kesimpulan hilang (ommited conclusion/oc). } \\ \text { K5 } & \text { : Konflik level respon (response level conflict/rlc). } \\ \text { K6 } & : \text { Manipulasi tidak langsung (undirected manipulation/um). } \\ \text { K7 } & : \text { Masalah hirarkhi keterampilan (skills hierarchy problem/shp). } \\ \text { K8 } & :(\text { above other/ao). } \\ & : \text { jawaban benar } \\ & : \text { tidak ada jawaban }\end{array}$

\section{Ucapan Terima Kasih}

Ucapan terimakasih penulis kepada kepala sekolah, guru Matematika, dan siswa kelas VIII SMP Negeri 10, Tanjungpinang serta kepada Dosen Pendidikan Matematika, Febrian, S.Pd., M.Sc, yang telah membimbing pelaksanaan studi analisis kesalahan dan penulisan artikel imliah ini. Kemudian rekan-rekan penaganalisis, mahasiswa Pendidikan Matematika FKIP Universitas Maritim Raja Ali Haji yang turut membantu perencanaan, pelaksanaan, dan penulisan.

\section{Referensi}

Soedjadi. (2000). Kiat Pendidikan Matematika di Indonesia. Jakarta: Departemen Pendidikan Nasional

Winasrsih, K. A, Sugiarti, T. (2015). Analisis Kesalahan Siswa Berdasarkan Kategori Kesalahan Menurut Watson dalam Menyelesaikan Permasalahan Pengolahan Data Siswa Kelas VI SDN Baletbaru 02 Sukowono Jember Tahin Pelajaran 2014/2015. Jember: Eniversitas Jember

Mahendra, N. C., Dafik, Setiawan. (2013). Penerapan Metode Inquiry untuk
Mengurangi Kesalahan Siswa dalam Menyelesaikan Soal pada Materi Aritmatika Sosial Kelas VII B Semester Ganjil SMPN 1 Sukowono Tahun Pelajaran 2012/2013. Jember: Universitas Jember. 
JURNAL GANTANG Pendidikan Matematika FKIP - UMRAH

Vol. 1 No. 2, Desember 2016, p-ISSN. 2503-0671, e-ISSN. 2548-5547 